\title{
EMPIRICAL RELATIONSHIP BETWEEN MACROECONOMIC VARIABLES AND STOCK PRICES OF INDIAN BANKING SECTOR: A VECTOR ERROR CORRECTION MODEL APPROACH
}

\author{
AASTHA KHERA AND NEELAM DHANDA
}

\begin{abstract}
This existing study aims to investigate the relationship between Indian Banking stock market prices and macroeconomic variables. The proxy for the Indian Banking stock market is Nifty Bank while Foreign Reserve, Exchange Rate (Indian vs US Dollar), Interest rate, and CPI are proxies of macroeconomic variables. Johansen Cointegration and Vector Error Correction Model (VECM) on monthly data from January 2013 to July 2020 have been applied. Considering the results of cointegration, it is found that there is a long-run association between the Indian Banking stock market and constituent macroeconomic variables. Next, the employment of VECM is done for inspecting long run and short-run causality. The result reveals long-run equilibrium in Indian commercial bank's stock prices coming from macroeconomic variables. This study has considerable imputations that investors can diversify their portfolio according to the influencing power of constituent selected macroeconomic variables in the short run and the long run. Exchange rate and foreign reserves drive the banking stock market in the short run whereas CPI and Interest rate do not create any significant impact.
\end{abstract}

\section{INTRODUCTION}

The banking sector is termed as the backbone of the nation's financial strength. It drives the growth and development of a country through the mobilization of funds. Banks are distinctive in providing valued products and services to customers in developed and as well as developing countries for strengthening their prosperity (Bonston, 2004). Banks are an important component of the financial system of the country. Well established financial markets drive the progress of economic expansion through the structured allocation of resources. The efficiency of these markets is the key to the speedy financial progress of the country. The job of financial markets is to make use of capital resources efficiently and worthily (Ahuja et. al, 2012). Stock markets clear the way for the movement of funds from savers to the investors. So its productive working paved the way for the financial success of the country.

The banking sector is vital in creating prosperity for the nation. Banking sector stocks are prominently tracked by investors and had been a great option for wealth creation. They are the preferred choice of mutual fund managers ${ }^{1}$. After the liberalization of the banking sector in India, this sector gained substantial importance.

Received by the editors November 19, 2020. Accepted by the editors December 21, 2020.

Keywords: Indian Banking Stock Market, Macroeconomic Variables, Long Run Equilibrium, Short Run Equilibrium, Johansen Cointegration, Vector Error Correction Model.

JEL Classification: C58, C54, D53, G21.

Aastha Khera, Research Scholar, Department of Commerce, Kurukshetra University, Kurukshetra, India. E-mail: aasthakhera12@gmail.com.

Neelam Dhanda, PhD, Professor, Department of Commerce, Kurukshetra University, Kurukshetra, India. E-mail: ndhanda@kuk.ac.in.

This paper is in final form and no version of it will be submitted for publication elsewhere.

${ }^{1}$ See Deployment of Funds by All Mutual Funds, Securities and Exchange Board of India, available at: https://www.sebi.gov.in/statistics/mutual-fund/deployment-of-funds-by-all-mutual-funds.html. 
The Indian Banking sector is the fusion of Nationalised Banks, new and old private sector Banks, new private sector banks, and foreign sector banks (Banerjee, 2005). The significance of public ones is on the reducing side and their share in Nifty bank is around $12 \%$. Scheduled commercial banks consist of twelve Public sector banks and 22 private sector banks. 46 scheduled foreign banks are operating in India. Reserve Bank of India is the central bank overseeing the operations of all the existing banks. The Banking Companies Act, 1980 states the Indian government ownership of not less than $51 \%$. The Indian government had a very tight dominance over the Indian banking sector till the 1990s. These public sector banks where government commands the ownership holds of about $90 \%$ of the banking sector's assets. This led to the inefficient working of the banking sector performance.

This sector underwent liberalization in the year 1991, intending to improve the effectiveness, fitness, and productivity (Ghosh, 2011). Next empowering regulations were taken by the Indian government in 1998 that fosters the market-driven growth of the Banking sector. The prominent part of this liberalization process is the deregulation of the interest rate. As a result of this, Indian banks shifted from a completely controlled system of interest rate to a market-driven system (Chakrabarti, 2005). RBI promoted the competitiveness of the industry through the allowance of private sector banks and foreign banks. The entry of new private sector banks transformed the entire sector with the power of technology. New evolved products are being introduced, recent technology is the new parameter, and fierce business practices are the new place (Prasad and Ghosh, 2007). Another important contribution in this field by India's important stock exchange is the framing of the sectoral index.

Various stock market indexes have been formed for capturing specific industries. The index framed for gauging commercial bank's stock returns is the NiftyBank index. It consists of large liquid stocks and the highest market capitalized banking stocks. It is treated as a yardstick that encapsulates the capital market performance of banking stocks. It covers the twelve banks in the industry that are leading the banking market. So Nifty Bank is of prime importance to investors for tracking banks' stocks. It is ideally taken as representative for measuring the Banking sector stock market. High fluctuation is observed in NiftyBank thus making it prone to high risk as well as high returns.

The stock market has become vulnerable to dynamic policies and procedures during the post-1990s era. It is being impacted by a varied range of factors ranging from macro-economic to company-specific. Investors undertake the efforts for working out the factors impacting the stock market. Due to the globalization factor, international factors also create an impact on stock market returns. The probability of earning supernormal profits is hampered in the case of the efficient market hypothesis as it states the incorporation of all possible information (Fama, 1970). The semi-strong form involves the accommodation of public information and any new data in the market leads to an immediate change in the stock prices. Investors base their decision on the level of efficiency in the stock market. So investors endeavor and always keep an eye on the factors affecting the stock market.

In finance, a prominent theory explaining the relationship of macro-economic variables with the stock market returns is the Arbitrage pricing theory (Ross, 1976). It was formularized by the economist Stephen Ross in 1976. It is a multi-factor model that states that expected return can be forecasted by using the linear function of the anticipated return and various macroeconomic variables capturing systematic risk. Another important study in this field was done by Chen, Ross, and Roll(1986) that depicted the importance of macro-economic variables in the pricing of stock returns.

An extensive amount of literature is available for the stock market and its association with the macro-economic variables. Few studies have been carried out for specifically commercial bank's stock prices in India (Sebastian, 2012; Tripathi, Parashar, and Jaishwal, 2014). This paper attempts to study the short-run and long-run linkage between the commercial bank's stock returns and selected macro-economic variables that are Exchange rate, Inflation, Foreign reserves, and interest rates. This study has tried to accommodate the concerned variables in 
one place. This paper's analysis is partially similar to some of the existing studies. Sebastian (2012) proved the importance of exchange rate and interest rate in explaining Banking stock prices Foreign reserves and current account balance are significant in the study of Tripathi, Parashar, and Jaishwal (2014). This study proved the significance of the exchange rate and foreign reserves in impacting the banking stock market. Inflation has no considerable impact thus supporting Fama's proxy hypothesis (Fama, 1977).

The paper is constructed as follows- the first section covers the introduction part, the second portion is related to existing empirical studies, the third section covers the research methodology and data sources succeeded by empirical analysis. The final part concludes the paper with stated policy implications.

\section{Review of Literature}

An ample number of studies are there in the financial literature regarding the relationship of the stock market with the macro-economic variables. This section covers a brief overview of those studies.

Santoni (1986) studied the impact of inflation on the U.S commercial bank's stock returns. An inverse relationship is established between share prices and an expected inflation rate through regression analysis. Bank shareholders took advantage when inflation rates fell. Any unanticipated increase in inflation however may harm the wealth of shareholders.

Neih \& Lee (2001) studied the association of exchange rates and stock prices in the selected G7 countries. Unit root, Cointegration, and VECM model were used and no long-run significant relationship is found between these 2-time series. Short-term resulted in varied results as per the country. German's markets witnessed lower returns due to currency depreciation whereas it restores the markets in Canada \& the US. Two lead-lagged variables don't possess the power in the forecasting of another variable. The same sort of study was taken by Rahman \& Uddin (2008) for three South Asian countries. Markets of India, Bangladesh, and Pakistan were the sample selected. Monthly data is taken up and above-mentioned techniques in addition to the Granger-causality test are applied. Same results have been observed of no long-run relationship of exchange rates and stock prices. Both variables are not successful in causing each other. Abidini et. al (2013) re-established the same analysis of having no causation of exchange rates and the stock prices. This study has taken into account \& cities of Australia country. As per their studies, the exchange rate is not an influencing factor. Policymakers could not utilize individually the exchange rate to tap the markets.

Acikalin, et. al (2008) studied the association of the Istanbul stock exchange with the four selected variables namely GDP, exchange rate, interest rate, and current account balance. Causality test, cointegration, and VECM are applied on quarterly time-series data. Long term relationship is found between the variables and the index. One-sided causality is run from the variables to the Turkish market's index. Ballestar et. al (2009) employed a panel data technique for analyzing factors for the interest risk rate exposure of the Banking sector in the Spanish financial markets. The period consists of twelve years from 1994 to 2006 . Bank's weekly stock return is the dependent variable. On and off-balance sheet activities are considered as explanatory variables. Bank size, derivative activities, and proportion of loans to total assets came out to be significant determinants for the banks' interest rate exposure.

Berganza \& Broto (2012) employed a panel data technique for analyzing the link between exchange rate volatility, inflation targets, and foreign exchange interference. Two groups were formed, one with targeted inflations and the other with non-targeting ones. The movements of foreign exchange especially the ones done unfavorable like sale of foreign reserves are powerful in minimizing the impact of exchange rate volatility under flexible IT regime as compare to the ones with non targeted countries.

Ray (2012) analyzed the relationship of foreign exchange reserves with the BSE market capitalization. For this purpose unit root testing, linear regression, and Granger causality tests are applied. Foreign reserves are found to be impacting the stock market whereas the stock 
market does not cause so. These techniques are applied to the annual data concerning 10 years from 1991 to 2011.

Sebastian (2012) studied the macro-economic indicators that are creating an impact on banking stocks prices. Concerned variables are interest rate, exchange rate, and inflation, and their monthly frequencies are taken. Unit root testing, OLS, Cointegration, and VECM are applied for analysis. NiftyBank's own lagged values are best in explaining stock returns. Foreign exchange rates are prominent in having a significant impact on stock prices. Positive changes in exchange rates and interest rates create an impact negatively on the stock prices

Nkechukwu et. al (2013) attempted to study the annual data of the Nigerian stock market from 1980 to 2013. OLS regression, cointegration, and VECM are applied to the data. Two broad economic variables are taken GDP and Money supply. The long-run negative effect is found from GDP on the stock prices whereas money supply is significantly and positively linked with the market. The one-sided causal effect is from Stock prices to the GDP.

Al-Majali et. al. (2014) studied Jordan's stock market and its relationship with the Real Gross Demotic Product, Consumer Price Index, Credit to Private Sector, and Weighted Average Interest Rate on Time Deposit. Dummy variables are also inculcated to measure the impact of the global financial crisis. Along with cointegration and VECM, impulse response and variance decomposition are also employed. The most significant factor for the stock market index came out to be the weighted average interest rate on time deposits.

Tripathi, Parashar, and Jaishwal (2014) analyzed the relationship between selected macro variables and various sectoral indexes. Multiple regression model is applied and a high level of correlation is ascertained. Crude oil price is not a significant factor in the case of the NiftyBank index. Foreign exchange reserves are a considerable factor in the case of the energy and Bank index.

Suciningtias (2019) analyzed the impact of interest rate, inflation, gold prices, and oil prices on Islamic Bonds. Long term impact is driven by interest rate, exchange rate, and oil prices on the performance of the index as explained by VECM. In the short-run, its own lagged factors impact the bond's performance. Crude oil prices are insignificant in explaining the returns of Bond in the short run and as well long run. Gupta \& Kumar(2019) chose five sectoral indices and four macroeconomic variables for their study. Their period consists of 2010 to 2017. The rest of VECM stated the absence of long-run association of variables with the index except the NiftyRealty index. Gold prices impacted the Auto index in the short-run. FMCG companies are being impacted by variable industrial production. CPI and Exchange rate impacted the real estate companies.

Naseem et. al (2019) studied the long-run and short-run association of the Pakistan stock market index with major macro variables namely Inflation rate, interest rate, exchange rate, and money supply. Monthly time series is considered from 2009 to 2018 and the unit root test, Johansen Julius test, and Vector error correction model is employed for analysis. A long-run association is found among the variables Returns have a short-lived impact on money supply as proved through the out comings of Wald Test.

Golder et. al. (2020) specifically selected exchange rate, foreign reserves, and crude oil prices and their impact on the Dhaka stock exchange. Time series of monthly nature is considered and Granger causality test, cointegration, and VECM are applied. No Causal relationship is found with the crud-oil prices to the stock market whereas the stock market index is causing a direct impact on the foreign reserves and the exchange rate. The long-run impact is found with the help of the impulse response function.

\section{Data and Research Methodology}

The relationship of the Indian Banking stock market and macro-economic variables are being worked out by taking monthly data of five variables from year January 2013 to July 2020. These variables are Nifty Bank (benchmark index for the banking industry in India), foreign exchange 
reserves, exchange rate (USD/INR), long term interest rate, and Consumer Price Index of India. The properties of the data are analyzed through Descriptive statistics and Unit Root tests. Variables are converted into their first difference for computations. Johansen's Cointegration test is employed followed by the Vector error correction model to examine the long-term relationships and short-run causalities among the banking stock index and the variables. In the end, the Wald test is applied for scrutinizing the direction of causality.

3.1. Johansen's cointegration test. Initially, the level of integration of variables is worked out through a stationarity check. Augmented Dicker fully (ADF) test and Philip perrons (PP) test. I(0) means integration at the level whereas I(1) means achieving stationarity after being transformed into their first difference. So, cointegration is applied to the non-stationary series for investigating long-term association among the time series. There are two widely known methods for calculating cointegration: the two-step Engle and Granger (1986) and Johansen's cointegration test (1988). In this paper, there are five variables to be studied, So Johansen's cointegration is selected. Further, Johansen's test has two variants that are Trace and Maximum Eigenvalue which are put down as follows:

$$
\begin{gathered}
\infty_{\text {trace }}(m)=-T \sum_{i=m+1}^{g} \ln \left(1-\widehat{\infty}_{i}\right) \\
\infty_{\text {max }}(m, m+1)=-T \ln \left(1-\widehat{\infty}_{m+1}\right)
\end{gathered}
$$

Acceptance and rejection of the null hypothesis are based on values of the test statistic and critical value. If the critical value comes out to be lower than the test statistic, then it means that there are $m$ cointegrating vectors in respect of $m+1$ (for $\infty_{\text {trace }}$ ) or more than $m$ (for $\left.\infty_{\max }\right)$. and the null hypothesis tends to be rejected. It is formulated in a pattern taking, $r=0,1, \ldots . ., g-2$ so that proposition for $\infty_{\max }$ is:

$H 0: m=0$ versus $H 1: 0<m=g$

$H 0: m=0$ versus $H 1: 1<m=g$

$H 0: m=0$ versus $H 1: 2<m=g$

$H 0: m=g-1$ versus $H 1: m=g$

This study covers a total of 5 variables, thereby $g$ is 5 . The alternative hypothesis states that there are cointegrating vectors. If we reject an alternative hypothesis, it means that there are no cointegrating vectors. When the Null hypothesis is rejected, it specifies that cointegration exists and one equation would be formed (i.e., Ho:m=1). So every proposition would be checked until it is accepted. This test investigates the presence or absence of long-run association among the variables namely Nifty Bank index, Exchange rate, Foreign reserves, Interest rate, and Inflation.

3.2. Vector error correction model (VECM). The precondition for applying VECM is that all series must be stationary at their first difference. Due to this property, a Cointegration test has been applied. The absence of it leads to the usage of the VAR model and the presence of long-term association leads to the application of VECM. As the long term relationship among the variables is established but there could be short-run disequilibrium that is checked through VECM. So VECM is applied for investigating the short-run disequilibrium and for working out the correction rate to achieve the long-run association among the variables. VECM model is presented as follows:

$$
\triangle z_{t}=\pi z_{t-s}+\Gamma_{1} \triangle z_{t-1}+\Gamma_{2} \triangle z_{t-2}+\ldots+\Gamma_{s-1} \triangle z_{t-(s-1)}+e_{t}
$$

In which, $\pi=\left(\sum_{i=1}^{s} \beta_{i}\right)-I_{m}$ and $\Gamma_{i}=\left(\sum_{j=1}^{i} \beta_{j}\right)-I_{m}$

Under the detailing of the model, LHS included $\mathrm{n}$ variable on its first transformed form, whereas RHS includes lagged values of regressed variables and explanatory variables have got a coefficient matrix attached and $e_{t}$ is the error term. Succession to the property of cointegration, 
an error correction term is there that denotes the speed at which dependent variable adjusts to achieve the equilibrium and working of short-run dynamics also impacts the change of position (Engle and Granger, 1987). Variation in the regressed variables is the result of the extent of disequilibrium in the cointegrating relationship that is depicted by the error correction term along with the deviations in the explanatory series. The process of error correction is a method to synchronize the operations of both short and long-run conduct through the workings in the short run. Loss of equilibrium is befitted from the last period to the consequent period through this error correction procedure. Error correction terms lay down the long-term association and its t statistic value shows its level of significant or insignificant relation with the dependent variable. In last, the Wald test is conducted for examining short-term association its coefficients along with their t-statistic value explains the significance of differenced independent variables. Differentiation of long-term and short-term relationship is covered by VECM as it grabs both short-run mobility and long term interdependence among the variables.

\section{Results and Discussion}

Descriptive statistics and unit root testing has been performed to study the statistical properties of the data. Table 1 represents the summary statistics of the variables namely of DBankNifty, Dforeign Reserve, Dexchange, and Dcpi. The average of DNiftybank is highest (97.32) and the lowest is of Dintrate (-0.010). The volatility of the NiftyBank index is highest among all that is calculated by the standard deviation. Except for Dbanknifty, all the others have positive skewness. It implies the possibility of negative earnings from these is low whereas Nifty bank has the options of negative earnings. DNiftyBank and Dexchange have high kurtosis values. There could be high as well as low values. Dforeignreserves, Dinitrate, and Dcpi are normally distributed series as p-values are greater than $5 \%$.

\begin{tabular}{|l|r|r|r|r|r|}
\hline \multicolumn{7}{|c|}{ Table 1: Summary Statistics of constituent variables } \\
\hline \multicolumn{1}{|c|}{ Statistics } & DNIFTYBANK & DFOREIGN RESERVE & DEXCHANGE & DINTRATE & DCPI \\
\hline Mean & 97.32079 & 2.374157 & 0.239000 & -0.010140 & 0.529213 \\
\hline Maximum & 3636.900 & 13.30000 & 3.800000 & 0.603000 & 2.700000 \\
\hline Minimum & -10003.15 & -8.400000 & -2.042100 & -0.531000 & -1.800000 \\
\hline Std. Dev. & 1649.805 & 5.067713 & 1.027835 & 0.193902 & 0.809911 \\
\hline Skewness & -2.544830 & 0.083946 & 0.855612 & 0.262969 & 0.098581 \\
\hline Kurtosis & 17.09597 & 2.388182 & 5.049441 & 3.805047 & 3.329070 \\
\hline Jarque-Bera & 832.8955 & 1.492638 & 26.43485 & 3.429143 & 0.545717 \\
\hline Probability & 0.000000 & 0.474109 & 0.000002 & 0.180041 & 0.761200 \\
\hline Observations & 89 & 89 & 89 & 89 & 89 \\
\hline \multicolumn{7}{|c|}{ Source: Author's presentation } \\
\hline
\end{tabular}

The next step is to look out for the stationarity status of all the series.

\begin{tabular}{|c|c|c|c|c|c|c|c|c|c|}
\hline \multicolumn{10}{|c|}{ Table 2: Result of ADF and PP Test for Unit Root } \\
\hline Variables & \multicolumn{4}{|c|}{ Augmented Dickey-Fuller Test } & \multicolumn{4}{|c|}{ Phillips-Perron Test } & \multirow{3}{*}{$\begin{array}{c}\text { Inference on } \\
\text { Integration } \\
\mathrm{I}(1)\end{array}$} \\
\hline & \multicolumn{2}{|c|}{ Levels } & \multicolumn{2}{|c|}{ First Difference } & \multicolumn{2}{|c|}{ Levels } & \multicolumn{2}{|c|}{ First Difference } & \\
\hline BANKNIFTY & -1.529955 & 0.5140 & -9.888480 & 0.0000 & -1.532146 & 0.5129 & -9.877423 & 0.0000 & \\
\hline FOREIGN RESERVE & 0.988542 & 0.9962 & -5.509311 & 0.0000 & 1.301393 & 0.9985 & -5.507794 & 0.0000 & $\mathrm{I}(1)$ \\
\hline EXCHANGE RATE & -1.348647 & 0.6038 & -8.025302 & 0.0000 & -1.445345 & 0.5565 & -8.029704 & 0.0000 & $\mathrm{I}(1)$ \\
\hline INTEREST RATE & -1.851058 & 0.3538 & -6.468938 & 0.0000 & -1.593093 & 0.4819 & -6.384353 & 0.0000 & $\mathrm{I}(1)$ \\
\hline CPI & -0.852408 & 0.7987 & -6.385036 & 0.0000 & -0.932412 & 0.7736 & -6.375348 & 0.0000 & $\mathrm{I}(1)$ \\
\hline
\end{tabular}

The results are depicted in Table 2. ADF test and PP tests are applied on all the series. The null hypothesis is accepted at a level as p- values are greater than 5\%. Then the series is converted into their first difference. Integrated series showed the presence of stationarity. 
Both the tests prove the evidence of non-stationarity in their level form. This completes the precondition of same order integration of all series for applying cointegration. Each series is integrated at I(1). So Johansen's test was employed for studying the long-term relationship.

Figure1 represents the graphs of Differenced time series namely DNiftyBAnk, Dcpi, Dintrate, Dexchangerate, and Dforeignreserves. It seems that they are co-moving. The variables could only depict cointegration when they are non-stationary and integrated of the same order. So in addition to a graphical representation, Johansen's Cointegration test is also employed. Table 3 disclosed the results of the cointegration test through trace statistics $\left(\lambda_{\text {trace }}\right)$ and maximal eigenvalue $\left(\lambda_{\max }\right)$. It represents the long-run association among the selected variables. The null hypothesis that holds of no cointegrating relationship of the Bank Nifty, Interest rate, exchange rate, inflation, and foreign reserves is rejected as trace statistic (119.3673) is greater than its critical value of $5 \%$ that is 69.81 . Eigenvalue also tells the same picture of hypothesis rejection. So depending upon the data of 5 variables, 4 cointegrating equations can be made at most 1 to 4 . Results stated that at most 4 vectors could be formulated. Evidence paved the way for a long run association. This further makes an addition that any short term disequilibrium could be corrected. Temporal causality could be observed among the component variables when they are cointegrated (Miller, 1991). Reasons for alteration in the variables could e attributed to the two factors. The first is due to the short-run interlinkage among the variables and the second force represents the accommodating force done by variables to correct the divergence through the equilibrium method and that is completed by Error Correction Model. So following this, Vector Error Correction Model is employed for examining short-run dynamic adjustment.

Figure 1: Graphs of Differenced form
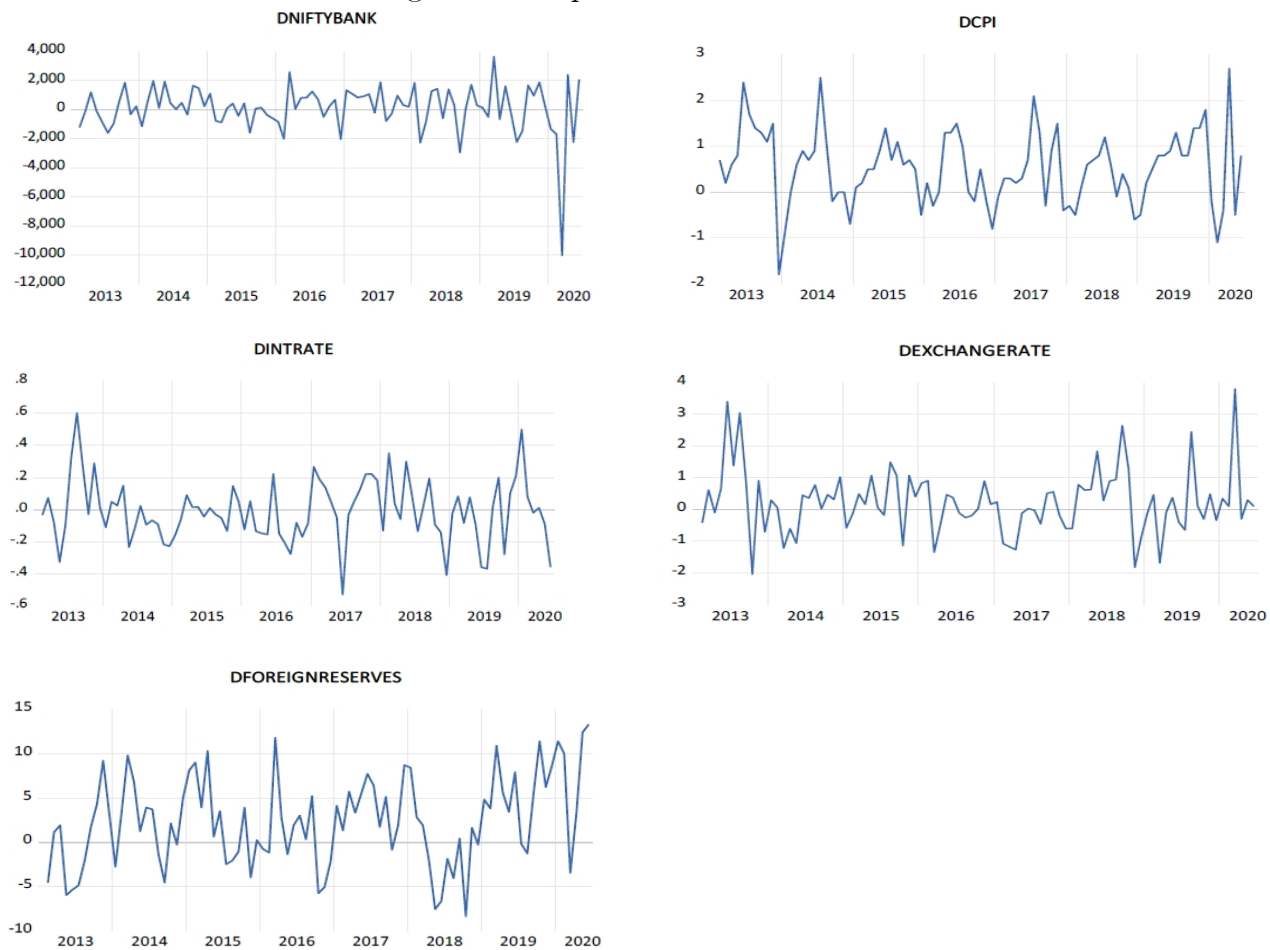

The analysis of the vector error correction model is presented in table 4 along with the coefficients and t-statistic. In the present study, DNiftyBank is the target variable or dependent variable, and Dforeign Reserve, Dexchange, Dintrate, and Dcpi are explanatory variables. Both long-run and short-run effects are encapsulated by VECM. Before the application of VECM, Akaike Information Criteria (AIC) is used for optimal lag selection. Lag 2 is found to be an appropriate one. Speed of adjustment or error correction term came out to be -1.116833 and 
t-statistic is also significant. This indicates that prior period disequilibrium is corrected at a speed of $111 \%$ in the short-run meaning every month.

\begin{tabular}{|c|c|c|c|c|}
\hline \multicolumn{5}{|c|}{ Table 3: Johansen Cointegration Test } \\
\hline \multicolumn{5}{|c|}{ Trace Test Statistics $\left(\lambda_{\text {trace }}\right)$} \\
\hline No. of Cointegrating Equations & Eigenvalue & Trace Statistic & Critical Value & Prob. $^{* *}$ \\
\hline $\mathrm{r}=0$ & 0.361873 & 119.3673 & 69.81889 & 0.0000 \\
\hline $\mathrm{r}=1$ & 0.324336 & 80.73462 & 47.85613 & 0.0000 \\
\hline $\mathrm{r}=2$ & 0.236603 & 47.01756 & 29.79707 & 0.0002 \\
\hline $\mathrm{r}=3$ & 0.170491 & 23.79956 & 15.49471 & 0.0022 \\
\hline $\mathrm{r}=4$ & 0.085903 & 7.724365 & 3.841465 & 0.0054 \\
\hline \multicolumn{7}{|c|}{ Maximal Eigenvalue Statistics $\left(\lambda_{\text {max }}\right)$} \\
\hline $\mathrm{No}$ of Cointegrating Equations & Eigenvalue & Max-Eigen Statistic & Critical Value & Prob. $^{* *}$ \\
\hline $\mathrm{r}=0$ & 0.361873 & 38.63268 & 33.87687 & 0.0125 \\
\hline $\mathrm{r}=1$ & 0.324336 & 33.71705 & 27.58434 & 0.0072 \\
\hline $\mathrm{r}=2$ & 0.236603 & 23.21800 & 0.0251 \\
\hline $\mathrm{r}=3$ & 0.170491 & 16.07520 & 21.13162 & 0.0256 \\
\hline & 0.085903 & 7.724365 & 3.841465 & 0.0054 \\
\hline \multicolumn{2}{|c|}{ Source: Author's own presentation } \\
\hline
\end{tabular}

Speed of adjustment is substantially considerable for correction of disequilibrium to arrive at a long-run equilibrium position. Inference of this part is that when the series that are cointegrated experience the disequilibrium in a short period, DNiftyBAnk modifies itself to come up to maintain equilibrium; it is understood that Dependent variables share a long-run equilibrium position with the other variables. Analyzing the short term, DNiftyBAnk is not significant at both levels which consider its null autocorrelation. In addition, Dcpi is also not considerable at both the lags. Dintrate also follows the same picture of having no autocorrelation at both the lags. Dexchange rate is significant at lag 1 but not in the case of lag 2 implying the autocorrelation presence at lag 1 only. The last series Dforeignreserve is also significant at lag 1 only.

\begin{tabular}{|c|c|c|}
\hline \multicolumn{3}{|c|}{ Table 4: Result of Vector Error Correction Model (VECM) } \\
\hline & Dependent Variable & \\
\hline & DNIFTYBANK (Coefficients) & t-statistics \\
\hline VEC Long Run Causality & & \\
\hline Error Correction Term & -1.116833 & {$[-3.81257]$} \\
\hline Independent Variables & DNIFTYBANK & \\
\hline D(DNIFTYBANK(-1)) & -0.039076 & {$[-0.16733]$} \\
\hline D(DNIFTYBANK(-2)) & 0.068568 & {$[0.43351]$} \\
\hline D(DCPI(-1)) & 48.68113 & {$[0.18736]$} \\
\hline D(DCPI(-2)) & 155.6969 & {$[0.58879]$} \\
\hline D(DINTRATE(-1)) & 395.9032 & {$[0.38781]$} \\
\hline D(DINTRATE(-2)) & 1080.369 & {$[1.04046]$} \\
\hline D(DEXCHANGE(-1)) & 1146.067 & {$[3.17523]$} \\
\hline D(DEXCHANGE(-2)) & 411.2985 & {$[1.60629]$} \\
\hline D(DFOREIGNRESERVE(-1)) & 167.8239 & {$[2.70889]$} \\
\hline D(DFOREIGNRESERVE(-2)) & 54.60337 & {$[1.02516]$} \\
\hline \multicolumn{2}{|c|}{ Source: Author's presentation } \\
\hline
\end{tabular}

The next step involves the testing of short-run causality checks for DNiftyBank. Wald test is employed for this purpose and results are in Table 5 . The optimal lag is 2 for the existing study. So the wald test is grounded on maximum lag 2. DNiftyBank is taken at their lag 2 for checking the short-run causality to itself as it is the regressed variable in the study. So p-value comes out to be significant. It could be stated the there exist short-run causation from DNiftyBank 
to DniftyBank itself. Dcpi does cause short-run causality to DNftyBank. In the same manner, Dintrate also has no short- term causation. Statistical significant results of the Wald test are found in the case of Dexchange and Dforeignreserves. These 2 series pose short-run causality to DNiftyBank.

Comprehensively, this study represented four cointegrating equations in which DNiftyBank is supposed to be associated with the rest of the variables namely Dcpi, Dintrate, Dexchange, and Dforeignreserves. Considering the short term, Dexchange, Dforeignreserves, and DNiftyBank itself created an impact on the dependent variable. (DNiftyBank).

\begin{tabular}{|c|c|c|c|}
\hline \multicolumn{5}{|c|}{ Table 5: Wald Test for testing short-run causality } \\
\hline Variables & Chi-Square & Degree of Freedom (DF) & P-value \\
\hline DNIFTYBANK & 15.65323 & 2 & 0.0476 \\
\hline DCPI & 0.348744 & 2 & 0.8400 \\
\hline DEXCHANGE & 10.34779 & 2 & 0.0057 \\
\hline DFOREXRESERVE & 7.782558 & 2 & 0.0204 \\
\hline DINTRATE & 1.102152 & 2 & 0.5763 \\
\hline \multicolumn{4}{|c}{ Source: Author's presentation } \\
\hline
\end{tabular}

\section{Conclusion of the Study and Policy Implication}

The purpose of the existing study is to examine the association of Banking stock returns (Nifty Bank) and constituent macro-economic variables. (CPI, Interest rates, Exchange Rate and Foreign Reserves) in the Indian financial market. The analysis is dependent on the monthly data concerning around 7 years from January 2013 to December 2020. The results evaluated are based on the Johansen Cointegration test and Vector error correction model. Cointegration is established between DNiftyBank and the other variables through the Johansen test. Additionally, VECM was applied for examining short-run and long-run causality. So overall, long-run equilibrium is established of the variables with the DNiftyBank as per the study. Exchange rate and foreign reserves are significant in the short-run also. It indicates the fact that long run disturbance is going to be erected. The banking stock market accommodates the macroeconomic happenings in the economic environment into its pricing in the short run. It facilitates the improved forecasting of NiftyBank after taking into accounts the movements of the exchange rate and foreign reserves.

Market kinetics could be different in different periods as per the study. These variations could be an important factor in formulating constructive policy instruments. Investors could utilize this information for modifying their portfolios depending upon the reaction of variables in short term and as well as the long run. This could equip the policymakers as well for making well-informed decisions. Confirmation of long term association among the variables put the theory of the efficient market hypothesis in apprehension. The Banking stock markets could be tapped in advance thereby becoming obstinate to the hypothesis of efficient markets. So Banking regulators like RBI have to keep these factors in mind regarding exchange rate and foreign reserves as they impact the Banking stock's returns in the short-run. The government can regulate international factors for managing the banking sector stock market.

The limitation of this study is that it is based on restricted time series data. This period selected is based on data availably of all these four variables. This could be termed as its restriction. The conclusions derived are based on only limited variables. A separate analysis of the Private and Public sector banking market is not there. This study could be further extended by accommodating more economic variables. Company-specific variables could also be included. The additional period could be involved. The experimentation of existing theories can be formularized in future studies. This paper has taken all the entire Banking stock market. Subdivision of the market into Private and Public sector banks is possible. Accordingly influencing macroeconomic factors could be worked out. 


\section{REFERENCES}

[1] Deployment of Funds by All Mutual Funds. Securities and Exchange Board of India. Available at: https://www.sebi.gov.in/statistics/mutual-fund/deployment-of-funds-by-all-mutual-funds.html.

[2] Abidin, S., Walters, C., Lim, K. L., \& Banchit, A. (2013). Cointegration between stock prices and exchange rates in Asia-Pacific countries. Investment management and financial innovations, 10(2), 142-146.

[3] Acikalin, S., Aktas, R., \& Unal, S. (2008). Relationships between stock markets and macroeconomic variables: an empirical analysis of the Istanbul Stock Exchange. Investment Management and Financial Innovations, 5(1), 8-16.

[4] Al-Majali, A. A., \& Al-Assaf, G. I. (2014). Long-run and short-run relationship between stock market index and main macroeconomic variables performance in Jordan. European Scientific Journal, 10(10), 156-171.

[5] Ballester, L., Ferrer, R., Gonzales, C., \& Soto, G. M. (2009). Determinants of interest rate exposure of Spanish banking industry. Department of Economics and Finance Working Papers DT-DAEF, 1.

[6] Banerjee, A.V. 2005. "Bank Competition in India." Working paper, Stanford Center for International Development, Stanford University, Stanford, CA.

[7] Benston, G. J. (2004). What's special about banks?. Financial Review, 39(1), 13-33.

[8] Berganza, J. C., \& Broto, C. (2012). Flexible inflation targets, forex interventions and exchange rate volatility in emerging countries. Journal of International Money and finance, 31(2), 428-444.

[9] Chakrabarti, R. 2005. "Banking in India-Reforms and Reorganization." Working paper, Indian School of Business, Hyderabad, India, January 17.

[10] Chen, N. F., Roll, R., \& Ross, S. A. (1986). Economic forces and the stock market. Journal of business, 383-403.

[11] Fama, E. F. (1970). Efficient capital markets: A review of theory and empirical work. The journal of Finance, 25(2), 383-417.

[12] Ghosh, S. 2011. "Does Activity Mix and Funding Strategy Vary Across Ownership? Evidence from Indian Banks." Atlantic Review of Economics 1, 1-33.

[13] Golder, U., Islam, M. N., \& Kayser, M. S. (2020). Impact of Foreign Exchange Reserve, Exchange Rate and Crude Oil Price on Dhaka Stock Exchange Index: An Empirical Evidence from Vector Error Correction Model. Indian Journal of Finance and Banking, 4(1), 134-143.

[14] Gupta, N., \& Kumar, A. (2019). Dynamic Relationship Between Stock Market Sector Indices and Macroeconomic Variables in India. International Journal of Applied Management Theory and Research (IJAMTR), $1(2), 31-41$.

[15] Miller, S. M., \& Russek, F. S. (1991). The temporal causality between fiscal deficits and interest rates. Contemporary Economic Policy, 9(3), 12-23.

[16] Naseem, S., Fu, G. L., ThaiLan, V., Mohsin, M., \& Zia-Ur-Rehman, M. (2019). Macroeconomic Variables and the Pakistan Stock Market: Exploring Long and Short run Relationship. Pacific Business Review International, 11(7), 621-72.

[17] Nieh, C. C., \& Lee, C. F. (2001). Dynamic relationship between stock prices and exchange rates for G-7 countries. The Quarterly Review of Economics and Finance, 41(4), 477-490.

[18] Nkechukwu, G., Onyeagba, J., \& Okoh, J. (2013). Macroeconomic variables and stock market prices in Nigeria: A co-integration and vector error correction model tests. International Journal of Science and Research (IJSR), 4(6), 717-724.

[19] Prasad, A., and S. Ghosh. 2007. "Competition in Indian Banking: An Empirical Evaluation." South Asia Economic Journal 8, no. 2: 265-284

[20] Rahman, M. L., \& Uddin, J. (2009). Dynamic relationship between stock prices and exchange rates: Evidence from three South Asian countries. International Business Research, 2(2), 167-174.

[21] Ray, S. (2012). Foreign exchange reserve and its impact on stock market capitalization: Evidence from India. Research on Humanities and Social Sciences, 2(2), 46-60.

[22] Ross, S. A. (1976). The arbitrage theory of capital asset pricing.Journal of Economic Theory,13(3), 341-360.

[23] Ross, S. A. (2013). The arbitrage theory of capital asset pricing. In Handbook of the fundamentals of financial decision making, Part I, 11-30.

[24] Santoni, G. J. (1986). The effects of inflation on commercial banks. Federal Reserve Bank of St. Louis Review, 68(3), 15-26.

[25] Suciningtias, S. A. (2019). Macroeconomic Impacts on Sukuk Performance in Indonesia: Co-integration and Vector Error Correction Model Approach. Journal of Islamic Finance, 8, 117-130.

[26] Tripathi, L. K., Parashar, A., \& Jaiswal, S. (2014). Impact of Macroeconomic Variables on Sector indices in India. Pacific Business Review International, 6(12), 2-42.

[27] Vardar, G., Aksoy, G., \& Can, E. (2008). Effects of interest and exchange rate on volatility and return of sector price indices at Istanbul stock exchange. European Journal of Economics, 11, 126-35. 